\title{
Challenges Faced by Engineering Lecturers in Integrating Technical and Employability Skills in the Curriculum: A Case Study in Community College, Malaysia
}

\author{
Zaliza Hanapi, Mohd Safarin Nordin, and Arasinah Khamis
}

\begin{abstract}
This study was conducted in order to identify the challenges or problems faced by the lecturers of Skill Training Institutes in Malaysia, especially lecturers of Community College in the engineering field, in integrating technical and employability skills in teaching and learning. The respondents for this study are 197 engineering lecturers of College Community. This study adopted a quantitative research methodology and utilized questionnaire as the instrument of the study. Descriptive statistics such as frequency, mean and standard deviation were used to analyze the data of the study. Findings of the study show that for the integration of technical skill, the majority of respondents agreed that "the lack of proper equipment, which are in accordance with the teaching and learning process" is the main challenge or problem in the process of integrating technical skills in the curriculum. While for the integration of employability skills, the majority of respondents agreed that "they do not get a clear understanding on the importance of employability skills" is the main challenge or problem in the process of integrating employability skills in the curriculum. In addition, the majority of respondents showed their strong agreements on the challenges or problems encountered in integrating technical and employability skills in teaching and learning. Mastering the technical and employability skills for the students is indeed vital and it is an important criterion in getting employed. Therefore, every lecturer should play a role in educating students to become excellent human capital, who will develop the economy of a country.
\end{abstract}

Index Terms-Technical skills, employability skills, engineering lecturers, quantitative study.

\section{INTRODUCTION}

These days, a good academic achievement is no longer a guarantee for the graduates to be employed in Malaysia [1]. Graduates with good academic achievements have the advantage but it does not guarantee them to get jobs and does not prove that they are high competence workers. Ranjit [2] stated that there are ten main weaknesses among graduates in Malaysia, which include the weakness in management, problem solving, communication, leadership, creativity, critical thinking, proactive, self-confidence and skills to interact. These create difficulties for the graduates to get jobs that fit with their qualifications. Abd Hair [3] also stated that technical and employability skills become the determining factor for a graduate to get a job. Therefore, this shows the

Manuscript received January 11, 2014; revised March 14, 2014.

Zaliza Hanapi is with the University of Technology Malaysia (e-mail: chikiza_12@yahoo.com). importance of integrating technical and employability skills among graduates. Barrie [4] mentioned that in Australia, it becomes the responsibility of the university lecturers to integrate the characteristics of skilled graduates across the curriculum.

\section{The MARKetABILITY Problem AMONG ENGINEERING GRADUATES IN MALAYSIA}

The Institute of Technical and Vocational Education Training (TVET) aims to provide marketable skilled and semi-skilled workers in order to enhance the development of a high-income country. However, a statistic by World Bank Education revealed that Malaysia had only $28 \%$ of skilled human capital, whereas other countries (Singapore: 51\%, Finland: $43.8 \%$, Australia: $42.9 \%$, United Kingdom: $42.5 \%$ and Republic of Korea: $29.3 \%$ ) had a higher percentage of skilled human capital (10MP, 2010). This shows that there is a huge gap for Malaysia to achieve the status of a world-class human capital. In addition, nearly 80,000 technical graduates in Malaysia are still unemployed and they depend mostly on academic qualifications to get jobs and the graduates are also lack of employability skills. Ahmad Nabil [5] stated that Malaysia is in need of qualified and high-skilled workers and the quality of high-skilled workers is judged by the industry based on two aspects, which are technical skills and employability skills. According to Ahmad Rizal [6], most of the graduates from various Public Skills Training Institutes in Malaysia failed to be employed due to the lack of employability skills, which are required by the industry. In addition Azami [7] mentioned that currently many employers would choose engineering graduates, who have good communication skills and able to handle work-related problems in the recruitment process.

In addition, a study conducted by [8] revealed that almost $50.5 \%$ of technical graduates from one of the Public Skills Training Institutes in Malaysia did not get a job after nine months graduating from the institutions and the problem is caused by the lack of non-technical skills or employability skills by the graduates. The need of having employability and technical skills among graduates is indeed an important criterion, which enables them to be marketable in the job market. Therefore, it is important to include elements of technical and employability skills across the curriculum in every course or study field offered at each educational institution. 


\section{THE INTERGRATION OF TECHNICAL AND}

EMPLOYABILITY SKILLS IN TEACHING AND LEARNING

Patil and Codner [9] mentioned that among the important global competency components and need to be mastered by engineering students include; i) the awareness on political and global issues; ii) understanding on cross-cultural issues; iii) understanding on the nature of the globalisation of the engineering education; iv) knowledge related to international market of workforce and the surrounding of workplace; v) understanding on the international business, economy and world market; and vi) efficient in applying problem solving skill related to engineering. While Accredition Board of Engineering and Technology (ABET) [10] stated that cooperation skills, communication skills, data analysis skills, and problem solving skills as the type of competencies that should be mastered by engineering graduates.

Other than that, there are employers and industries in Malaysia that felt that the curriculum of Higher Educational Institutions should be redesigned because they found that most of the graduates produced by the institutions do not have a satisfactory level of job competence [11]. In addition, it is also found that currently, in recruiting new workers many employers favor engineering graduates, who have good communication skills and able to handle work-related problems. Generally, technical skills need to be mastered by the graduates as it is the core component, which enables graduates to be employment in the industry. Whereas, the employability skills refer to qualities and attitudes that a graduate should have in order to be marketable and become a competent and competitive worker. Thus, these two components play an important role in influencing the employability of a graduate.

Reference [12] pointed out that the factors that influence effective educational institutions are leadership, quality of curriculum, classroom climate, achievement-oriented, effective learning time, structured teaching and the recognition of success. The quality of the lecturers is one of the important factors that determine the quality of the graduates from a university. The lecturers are those who implement all the policies and goals set by the government through the Ministry of Education. Therefore, it becomes the responsibility of a lecturer to integrate various essential skills across the curriculum, which was developed by the curriculum developer.

Subsequently, this study was conducted to identify the challenges or problems faced by the lecturers at the Skills Training Institute in Malaysia, especially engineering lecturers at the Community College, in integrating technical and employability skills in teaching and learning. By successfully producing competent workforce, it is a prove on the importance of technical and vocational education in contributing to the country's economic growth and this is also a way to eliminate the perception of the community that consider technical and vocational education as a second-class education.

\section{Methodology}

This research employed quantitative research methodology and it involved 197 engineering lecturers from Community College, Malaysia. This research utilized descriptive analysis such as frequency, percentage, mean score and standard deviation in analyzing the data.

The respondents consist of $106(53.8 \%)$ male lecturers and 91 lecturers $(46.2 \%)$ female lecturers. From the aspect of highest academic qualifications, majority of respondents are bachelor's degree holder with a total of 117 people (59.4\%). fourty five respondents $(22.8 \%)$ are master's degree holder, 31 respondents $(15.7 \%)$ have Diploma in Skills and 2 respondents $(1.0 \%)$ have Technical Certificate and Diploma in Education.

From the aspect of teaching experience, it is found that 88 respondents $(44.7 \%)$ have teaching experience between 1 to 5 years, 82 respondents $(41.6 \%): 6$ to 10 years, 17 respondents $(8.6 \%)$ : 11 to 15 years; 4 respondents $(2.0 \%): 16$ to 20 years, and 2 respondents $(1.0 \%) 31$ to 35 years.

\section{FINDING OF THE STUDY}

In this section, the finding of this study is divided into two parts, which are the challenges in integrating technical skills and the challenges in integrating employability skills. For this study, the degree of the challenge in integrating technical and employability skills by the lecturers can be referred to Table I.

TABLE I: THE DEGREE OF CHALLENGE IN INTEGRATING TECHNICAL AND EMPLOYABILITY SKILLS BASED ON MEAN VALUE

\begin{tabular}{|c|c|c|}
\hline $\begin{array}{c}\text { Degree based } \\
\text { on Mean Value }\end{array}$ & $\begin{array}{c}\text { Degree } \\
\text { Type }\end{array}$ & \multicolumn{1}{|c|}{ Description } \\
\hline $1-2.33$ & Low & $\begin{array}{l}\text { Face easy challenges in integrating } \\
\text { skills in the teaching and learning } \\
\text { process. }\end{array}$ \\
\hline $2.34-3.67$ & Average & $\begin{array}{l}\text { Face average challenges in } \\
\text { integrating skills in the teaching and } \\
\text { learning process. }\end{array}$ \\
\hline $3.68-5.00$ & High & $\begin{array}{l}\text { Face difficult challenges in } \\
\text { integrating skills in the teaching and } \\
\text { learning process. }\end{array}$ \\
\hline
\end{tabular}

\section{A. Challenges in Integrating Technical Skills}

TABLE II: DESCRIPTIVE ANALYSIS: DiSTRIBUTION OF MEAN SCORES AND STANDARD DEVIATION FOR THE CHALLENGES IN INTEGRATING TECHNICAL

\begin{tabular}{|l|c|c|c|}
\hline $\begin{array}{l}\text { Challenges in } \\
\text { Integrating Technical } \\
\text { Skills }\end{array}$ & $\begin{array}{l}\text { Mean } \\
\text { Score }\end{array}$ & $\begin{array}{l}\text { Standard } \\
\text { Deviation }\end{array}$ & $\begin{array}{c}\text { Degree of } \\
\text { Challenges }\end{array}$ \\
\hline $\begin{array}{l}\text { Lack of proper } \\
\text { equipment required in } \\
\text { the teaching and } \\
\text { learning process }\end{array}$ & 3.995 & 1.047 & High \\
\hline $\begin{array}{l}\text { Lack of suitable items } \\
\text { required in the teaching } \\
\text { and learning process }\end{array}$ & 3.985 & 1.042 & Average \\
\hline $\begin{array}{l}\text { Lack of time allocated } \\
\text { for the process of } \\
\text { teaching and learning }\end{array}$ & 3.350 & 1.076 & Average \\
\hline $\begin{array}{l}\text { Unconducive teaching } \\
\text { and learning } \\
\text { environment }\end{array}$ & 3.345 & 1.179 & Average \\
\hline $\begin{array}{l}\text { Unsufficient number of } \\
\text { teaching staff }\end{array}$ & 3.426 & 1.174 & Average \\
\hline $\begin{array}{l}\text { Teaching in the } \\
\text { unspecialized field of } \\
\text { study }\end{array}$ & 3.624 & 1.20 & \\
\hline
\end{tabular}


Based on Table II, findings of the study show that the item "Lack of proper equipment required in the teaching and learning process" shows the highest mean value with the score of 3.995 ( $\mathrm{SD}=1.047)$ compared to other challenges in integrating technical skills. This indicates that the majority of respondents agree that the item is the biggest challenge in the process of integrating technical skills in teaching and learning. Whereas the item "Unconducive teaching and learning environment" shows the lowest mean score with 3.345 ( $\mathrm{SD}=1.179)$ as compared to other items and it indicates that the majority of respondents agree that the item is the smallest or easiest challenge in integrating technical skills in teaching and learning.

In addition, results in Table III depict that the majority of respondents show a high level of agreement for all items that represent the challenges in integrating technical skills in teaching and learning process. This signifies that all of the items are considered difficult challenges in integrating technical skills in teaching and learning process.

TABLE III: DESCRIPTIVE ANALYSIS: DISTRIBUTION OF THE DEGREE OF CHALLENGES IN INTEGRATING TECHNICAL SKILLS

\begin{tabular}{|l|c|c|c|}
\hline \multirow{2}{*}{$\begin{array}{l}\text { Challenges in } \\
\text { Skills }\end{array}$} & \multicolumn{3}{|c|}{ Degree of Challenges } \\
\cline { 2 - 4 } & $\begin{array}{c}\text { Low } \\
\text { Sor }\end{array}$ & $\begin{array}{c}\text { Average } \\
N(\%)\end{array}$ & $\begin{array}{c}\text { High } \\
\boldsymbol{N}(\%)\end{array}$ \\
\hline $\begin{array}{l}\text { Lack of proper } \\
\text { equipment required in } \\
\text { the teaching and } \\
\text { learning process }\end{array}$ & $17(8.6)$ & $30(15.2)$ & $150(76.1)$ \\
\hline $\begin{array}{l}\text { Lack of suitable items } \\
\text { required in the teaching } \\
\text { and learning process }\end{array}$ & $17(8.6)$ & $30(15.2)$ & $150(76.1)$ \\
\hline $\begin{array}{l}\text { Lack of time allocated } \\
\text { for the process of } \\
\text { teaching and learning }\end{array}$ & $36(18.3)$ & $72(36.5)$ & $89(45.2)$ \\
\hline $\begin{array}{l}\text { Unconducive teaching } \\
\text { and learning } \\
\text { environment }\end{array}$ & $43(21.8)$ & $63(32.0)$ & $91(46.2)$ \\
\hline $\begin{array}{l}\text { Unsufficient number of } \\
\text { teaching staff }\end{array}$ & $41(20.8)$ & $59(29.9)$ & $97(49.2)$ \\
\hline $\begin{array}{l}\text { Teaching in the } \\
\text { unspecialized field of } \\
\text { study }\end{array}$ & $33(16.8)$ & $45(22.8)$ & $119(60.4)$ \\
\hline
\end{tabular}

\section{B. Challenges in Integrating Employability Skills}

Based on Table IV, the item "Do not get a clear understanding on the importance of employability skills" shows the highest mean score with 3.457 ( $\mathrm{SD}=1.104)$ compared to other items of challenges in integrating employability skills. This shows that the majority of respondents agree that the item is the biggest challenge in integrating employability skills in teaching and learning. Meanwhile, the item "Do not receive any instruction to integrate elements of employability skills" shows the lowest mean score with $3.234(\mathrm{SD}=1.110)$ compared to other items and this indicates that the majority of respondents agree that it is the smallest or easiest challenges in integrating employability skills in teaching and learning.

Besides, Table $\mathrm{V}$ shows that the majority of respondents have a high level of agreement for all items of challenges in integrating employability skills in teaching and learning process. This indicates that all of the items are considered difficult challenges in integrating technical skills in teaching and learning process.
TABLE IV: DESCRIPTIVE ANALYSIS: DISTRIBUTION OF MEAN SCORES AND STANDARD DEVIATION FOR THE CHALLENGES IN INTEGRATING EMPLOYABILITY SKILLS

\begin{tabular}{|c|c|c|c|}
\hline $\begin{array}{l}\text { Challenges in Integrating } \\
\text { Employability Skills }\end{array}$ & $\begin{array}{l}\text { Mean } \\
\text { Score }\end{array}$ & $\begin{array}{l}\text { Standard } \\
\text { Deviation }\end{array}$ & $\begin{array}{l}\text { Degree of } \\
\text { Challenges }\end{array}$ \\
\hline $\begin{array}{l}\text { No element of employability } \\
\text { skills included in the } \\
\text { curriculum of this field of } \\
\text { study }\end{array}$ & 3.406 & 1.146 & Average \\
\hline $\begin{array}{l}\text { No assessment related to } \\
\text { employability skills included } \\
\text { in the curriculum of this field } \\
\text { of study }\end{array}$ & 3.350 & 1.118 & Average \\
\hline $\begin{array}{l}\text { Do not get a clear } \\
\text { understanding on the } \\
\text { importance of employability } \\
\text { skills }\end{array}$ & 3.457 & 1.104 & Average \\
\hline $\begin{array}{l}\text { Do not know the importance } \\
\text { of employability skills }\end{array}$ & 3.330 & 1.124 & Average \\
\hline $\begin{array}{l}\text { Do not receive any } \\
\text { instruction to integrate } \\
\text { elements of employability } \\
\text { skills }\end{array}$ & 3.234 & 1.110 & Average \\
\hline $\begin{array}{l}\text { Do not get the guidelines to } \\
\text { integrate elements of } \\
\text { employability skills }\end{array}$ & 3.360 & 1.063 & Average \\
\hline $\begin{array}{l}\text { Do not have enough time to } \\
\text { integrate elements of } \\
\text { employability skills during } \\
\text { teaching and learning } \\
\text { process }\end{array}$ & 3.294 & 1.10 & Average \\
\hline
\end{tabular}

TABLE V: DESCRIPTIVE ANALYSIS: DISTRIBUTION OF THE DEGREE OF CHALLENGES IN INTEGRATING EMPLOYABILITY SKILLS

\begin{tabular}{|c|c|c|c|}
\hline \multirow{2}{*}{$\begin{array}{l}\text { Challenges in Integrating } \\
\text { Employability Skills }\end{array}$} & \multicolumn{3}{|c|}{ Degree of Challenges } \\
\hline & $\begin{array}{c}\text { Low } \\
N(\%)\end{array}$ & $\begin{array}{c}\text { Average } \\
N(\%)\end{array}$ & $\begin{array}{l}\text { High } \\
N(\%)\end{array}$ \\
\hline $\begin{array}{l}\text { No element of employability } \\
\text { skills included in the } \\
\text { curriculum of this field of } \\
\text { study }\end{array}$ & $41(20.8)$ & $54(27.4)$ & $102(51.8)$ \\
\hline $\begin{array}{l}\text { No assessment related to } \\
\text { employability skills } \\
\text { included in the curriculum } \\
\text { of this field of study }\end{array}$ & $39(19.8)$ & $66(33.5)$ & $92(46.7)$ \\
\hline $\begin{array}{l}\text { Do not get a clear } \\
\text { understanding on the } \\
\text { importance of employability } \\
\text { skills }\end{array}$ & $37(18.8)$ & $58(29.4)$ & $102(51.8)$ \\
\hline $\begin{array}{l}\text { Do not know the importance } \\
\text { of employability skills }\end{array}$ & $44(22.3)$ & $60(30.5)$ & $93(47.2)$ \\
\hline $\begin{array}{l}\text { Do not receive any } \\
\text { instruction to integrate } \\
\text { elements of employability } \\
\text { skills }\end{array}$ & $48(24.4)$ & $68(34.5)$ & $81(41.1)$ \\
\hline $\begin{array}{l}\text { Do not get the guidelines to } \\
\text { integrate elements of } \\
\text { employability skills }\end{array}$ & $38(19.3)$ & $64(32.5)$ & $95(48.2)$ \\
\hline $\begin{array}{l}\text { Do not have enough time to } \\
\text { integrate elements of } \\
\text { employability skills during } \\
\text { teaching and learning } \\
\text { process }\end{array}$ & $45(22.8)$ & $63(32.0)$ & $89(45.2)$ \\
\hline
\end{tabular}

\section{DISCUSSION AND CONCLUSION}

Overall, findings of the study show that the majority of the lecturers agree that the "Lack of proper equipment required in the teaching and learning process" is a major challenge in the process of integrating technical skills in the curriculum. Findings of this study are similar with the findings research [13]. In the study, she revealed that the lecturers at the 
Polytechnics feel the difficulties in implementing the Outcomes Based Learning (OBE) approach in teaching are caused by factors such as unconducive classrooms and workshop infrastructure, lack of suitable equipment and a high the number of students in a class. Besides, a study [14] that involved students of the National University of Malaysia also found that the infrastructure problem, a high ratio of students and the students' dynamics are among the constraints in integrating employability skills in teaching and learning. These are among the factors that could weaken the commitment of the lecturers in integrating the skills.

Other that, the findings of this study is also consistent with a study conducted by Akmarya [15], in which it is found that community college graduates have a low skill in using technology when given task. This may be because the lecturers do not have sufficient suitable equipment in conducting teaching and learning process. This leads to the low proficiency graduates in using technology. Mastering the use of technology is indeed a part of the important technical skills and it is an asset for graduates in order for them to work in the industry. Thete [16] described that the quality of an education depends on the quality of teaching and learning, educational facilities and infrastructure, good curriculum and effective implementation.

For the integration of employability skills, the majority of respondents agree that "they do not get a clear understanding on the importance of employability skills" is a major challenge in the process of integrating the skills in the curriculum. Lecturers should have a solid foundation of knowledge in their areas of expertise, pedagogical skills and a few other basic skills to equip themselves before the process of teaching and learning. Reference [17] stated that among the components of employability skills that need to be mastered by each lecturer in order to implement the smart pedagogy are thinking skills, assessing skills, facilitation skills, assessing and evaluating skills, and computer skills. It is not sufficient if lecturers only have knowledge on the subjects alone.

A study conducted by Erdiana [18] at Faculty of Education in one of the universities in Malaysia found that the integration of employability skills in the subject by the lecturers at the faculty is at a low level. An assumption that can be made is the lecturers do not have a clear understanding on the importance of employability skills among graduates. Therefore, the lecturers do not emphasize on employability skills and do not properly integrate the skills in the teaching and learning process.

To conclude, data collected via the questionnaire show that the majority of lecturers have a high degree of agreement towards all items that represent the challenges in integrating technical and employability skills in teaching and learning. Ramlee [19] highlighted that technical and employability skills should be equally emphasized in the curriculum of technical and vocational education by integrating the skills in order to develop competent employees. Effective skills training will produce graduates, who are educated and high-skilled, before entering the working world. Besides, it would also produce graduates, who practice good work ethic and able to act proactively in solving a task. In fact, the global developments in this technological era require the graduates to master the technical and employability skills.

\section{REFERENCES}

[1] N. Azina and N. A. Ismail, "Graduate characteristics and unemployment: A study among Malaysian Graduate," International Journal of Business and Social Science, vol. 2, no. 16, 2011.

[2] Ranjit, TVET Presentation, 2010.

[3] A. H. Awang, "Potensi permintaan tenaga kerja berkemahiran dalam sektor perkilangan, pembinaan dan perkhidmatan di Malaysia," Laporan Projek, Universiti Kebangsaan Malaysia, 2007.

[4] S. C. Barrie, Understanding What We Mean by The Generic Attributes of Graduate, University of Sydney, Australia, 2006.

[5] A. Nabil, "Technical skills and non-technical skills: predefinition concept," in Proc. the IETEC'11 Conference, Kuala Lumpur, 2012.

[6] A. R. Madar, "Kemahiran employability bagi memenuhi keperluan industry," Prosiding SKIS, 2008.

[7] A. Zaharim, "A gap study between employers' perception and expectation of engineering graduates in Malaysia," in Proc. Internatinal Conference on Engineering Education, Heraklion, Greece, pp. 404-407, 2008.

[8] M. Rashid, M. Rashahidi, and M. R. dan M. Rashahidi, "The year 2004 polytechnic convocation survey," in Proc. National Seminar "The development of Technology and Technical-Vocational Education and Training in an Era of Globalization: Trend and Issues", Kuala Lumpur, 2005.

[9] A. Patil and G. Codner, "Accrediatation of engineering education review, observations and proposal for global accreditation," European Journal of Engineering Educations, vol. 32, no. 6, pp. 639-651, 2007.

[10] Accredition Board of Engineering and Technology (ABET), 2012.

[11] Study Report from the National University of Malaysia, Project Report, Universiti Kebangsaan Malaysia, 2007.

[12] W. K. Hoy and C. G. Miskel, Educational Administration: Theory, Research and Practice, New York: McGraw Hill, 2005.

[13] A. Yaman, N. B. C. Azemi, and F. Shamsudin, "Kesediaan pensyarah dalam perlaksaan pengajaran dan pemeblajaran," Jabatan Kejuruteraa N Elektrik, Politeknik Port Dickson, 2012.

[14] A. Hussaini, C. H. Azhari, D. A. Wahab, N. Ishak, and S. Rahaya Ariffin, "Penerapan kemahiran generik dalam pengajaran menggunakan model tersebati," Seminar Pengajaran dan Pembelajaran Berkesan, 2005.

[15] A. S. M. Akhir, Keberkesanan Latihan Kemahiran di Kalangan Pelatih Kolej Komuniti dalam Membantu Mendapatkan Pekerjaan, Ijazah Sarjana, Universiti Tun Hussein Onn Malaysia, Johor, 2005.

[16] A. R. Thete, "Quality assurance mechanism, dlm singh, R. K. quality education," Opportunities and Challenges in the 21st Century, Delhi: Abijeet Publc, pp. 31-40, 2003.

[17] K. B. Baharun, "Sekolah bestari: pedagogi abad ke-21 dan profesionalisme guru," Jurnal Pendidikan Guru, vol. 15, pp. 20-32, 2002.

[18] E. Timming, Kajian Kes Tahap Kesedaran Terhadap Kepentingan Kemahiran Generik di Kalangan Pelajar Fakulti Pendidikan Universiti Teknologi Malaysia, Ijazah Sarjana Muda, Universiti Teknologi Malaysia, Skudai, 2006.

[19] R. Mustapha et al, "K ekonomy and globalisation-are ours student ready?” Jurnal Personalia Pelajar, vol. 11, pp. 1-23, 2008.

Zaliza Hanapi has obtained her bachelor's degree in the field of technical and vocational education (civil engineering) in 2007 from Universiti Tun Hussein Onn, Malaysia and she earned her master's degree in the same field from Universiti Putra Malaysia in 2010. Currently, she is a Ph.D. student at Universiti Teknologi Malaysia and a lecturer in faculty technical and vocational education at Sultan Idris University Of Education, Malaysia. Her fields of research interest are curriculum development, psychology, human capital development and career, especially in the engineering field.

Mohd Safarin Nordin has obtained bachelor's degree in mechanical engineering in 1996 and in 2008 he earned his PHD in technical and vocational education from Universiti Teknologi Malaysia. Currently, he is a lecturer in faculty education at University Of Technology Malaysia, Malaysia. His fields of research are generic skills among graduate and community and designing product.

Arasinah Khamis has obtained her bachelor's degree in fashion design (UiTM Malaysia) in 1998 and obtained her master's degree in technical and vocational education in the field of home science education from Universiti Putra Malaysia in 2010. Mrs. Arasinah has received the copyright award for the CFaDC instrument in 2013 from Research Management Centre, Universiti Putra Malaysia for the product "Clothing Fashion Design Competency Instrument (LY2013001188)". 